This item was submitted to Loughborough's Research Repository by the author.

Items in Figshare are protected by copyright, with all rights reserved, unless otherwise indicated.

\title{
Neo-pluralism as a theoretical framework for understanding HRM in sub- saharan Africa
}

PLEASE CITE THE PUBLISHED VERSION

PUBLISHER

(c) Loughborough University

LICENCE

CC BY-NC-ND 4.0

REPOSITORY RECORD

Khan, Alhajie Saidy, and Peter Ackers. 2019. "Neo-pluralism as a Theoretical Framework for Understanding HRM in Sub-saharan Africa". figshare. https://hdl.handle.net/2134/2036. 
This item was submitted to Loughborough's Institutional Repository by the author and is made available under the following Creative Commons Licence conditions.

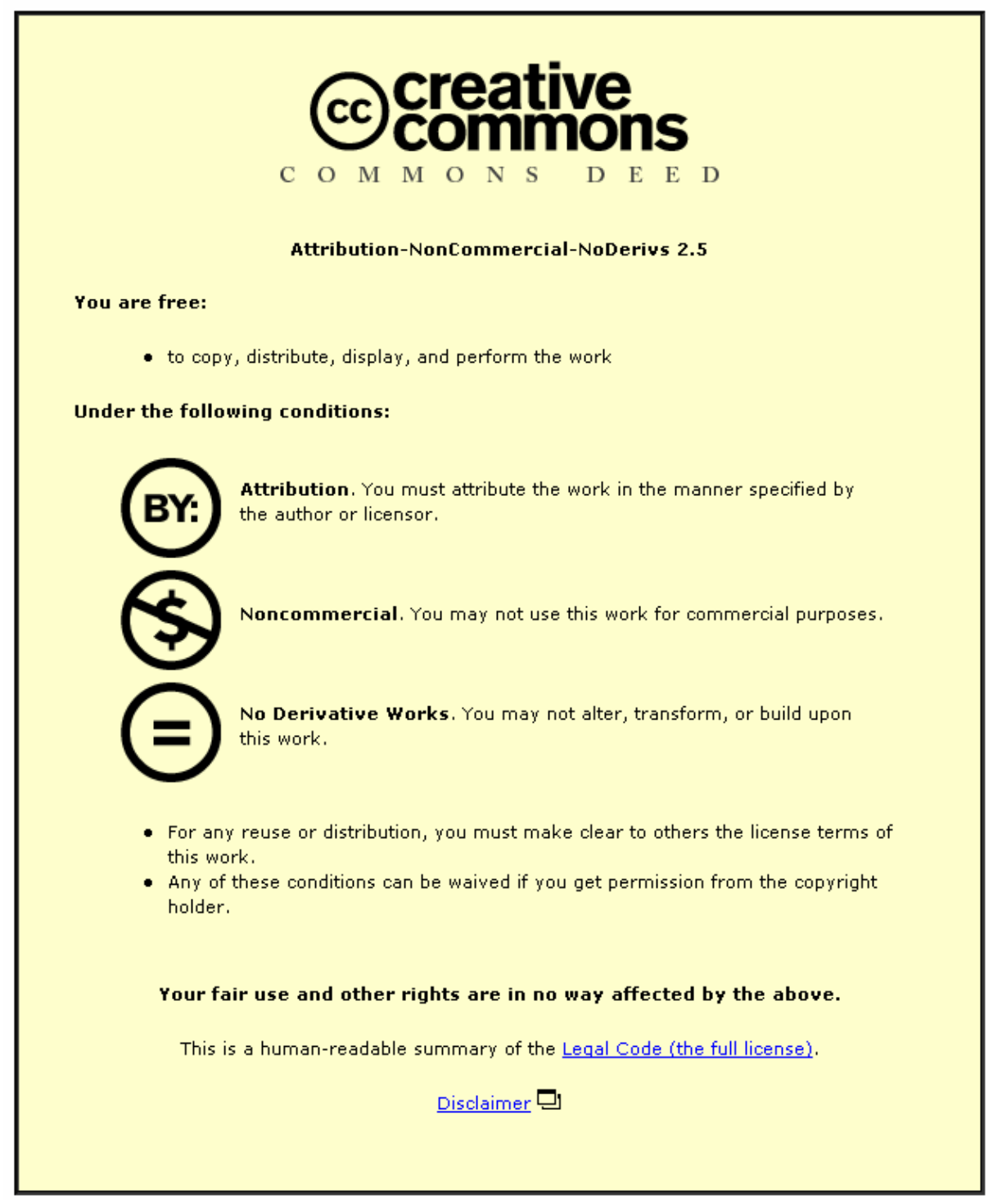

For the full text of this licence, please go to: http://creativecommons.org/licenses/by-nc-nd/2.5/ 
Neo-Pluralism as a

Theoretical

Framework for

Understanding HRM

in Sub-Saharan Africa

by Alhajie Saidy Khan and

Peter Ackers

\section{Business School}

Research Series

Paper 2003: 3

ISBN 1859011845 
Neo-Pluralism as a Theoretical Framework for Understanding HRM in Sub-Saharan Africa

\author{
by \\ Alhajie Saidy Khan and Peter Ackers \\ Business School Research Series \\ Paper 2003: 3 \\ ISBN 1859011845
}

April 2003

THIS PAPER IS CIRCULATED FOR DISCUSSION PURPOSES AND ITS

CONTENTS SHOULD BE CONSIDERED PRELIMINARY AND CONFIDENTIAL. NO REFERENCE TO MATERIAL CONTAINED HEREIN MAY BE MADE WITHOUT THE CONSENT OF THE AUTHORS. 
Neo-Pluralism as a Theoretical Framework for Understanding HRM in Sub-

\section{Saharan Africa}

\section{Alhajie Saidy Khan and Peter Ackers \\ Loughborough University Business School}

\section{Introduction}

'However far-reaching the political, economic, and psychological mechanisms through which imperial powers tried to make colonized peoples play their part in empire, they ultimately had to penetrate inside a plantation, a dockyard, a locomotive cab, or a factory where there were workers, bringing to the encounter their own conceptions of labour, their own interests, and their own wills' (Fredrick Cooper, 1987: 1).

The argument in this paper is made against the background of the adoption of the rhetoric of HRM and neo-liberal approaches to organisational analysis following the introduction of structural adjustment policies (SAP) in Sub-Saharan African (SSA). It is about the practice of employment management in a social context where values, beliefs and actions tend to challenge the notion that Western management practices are universally applicable. However, the issue is not just the suitability and contextual relevance of specific management theories and practices, but also whether the extent and nature of prevailing forms of analysis and the resultant suggestions regarding HRM models for SSA are appropriate and suitable. Here, we argue that most research undertakings concerned with management practices in SSA fail to take proper account of the normative traditional institutions and social structures of the wider society and their influences on individual conception of and attitudes towards waged labour. As a result, salient social issues that are central to the employment problem are subjected to superficial discussion and dismissed as irrelevant and incompatible with the rational values and objectives of the 'modern' business organisation. We attribute this to the predominance of a unitarist American approach to organisational analysis and the absence of a suitable theoretical framework that can take HRM policy beyond the workplace to incorporate a wider range of 'stakeholders' and emerging tensions over values as well as interests.

An exploration of the suitability of managerial theories and practices must, of necessity, consider cultural considerations that question the assumed universal applicability of existing managerial practices. In that respect, we discuss employment 
management and labour relations from a historical perspective. In particular, we focus on the social phenomena that capitalist approaches to work organisation and labour relations sought to address and question whether Western HRM, in the context of the organisational 'frames of reference' (Fox, 1966) on which it is based, represents a viable paradigm for this particular social context. On the basis of a review and analysis of the literature on organisational 'frames of reference' and employment management in SSA, we argue that the usual Western formulations of organisational reality do not constitute suitable frameworks for imagining contextually suitable models of HRM for SSA.

Western organisational analyses in SSA are disproportionately focused on internal organisational variables and for that matter, managerial concerns. In terms of the external context, the nation-state, with its institutional and legal frameworks, is considered to be the sole external variable that really matters. More enduring and legitimate traditional institutions and social structures, such as the extended family clans and religious brotherhoods are dismissed as archaic sources of inefficiency and corruption. In this respect, Western analyses of organisational phenomena in SSA are limited in terms of scope and the variables that are taken into account. American management research paradigms, that are the bases for more recent solutions to the employment problem (Berg, 1981; \& WB, 1989) have contributed to this discrepancy. However, a more important factor is the absence of alternative suitable theoretical frameworks that can embrace the broad spectrum of normative institutions and influences that shape the conceptions, attitudes and behaviours of the African worker.

The Unitarist perspective of the organisation does not accept the reality or potential for the existence of alternative interests and sources of authority even within the organisation. As a result, it cannot constitute the theoretical basis for managerial approaches in a context where external structures and authority relationships, with values and interests that may be wholly antithetical to those of the organisation, have significant influences on individual perceptions of the organisation's values, objectives, policies and practices. Traditional formulations of Pluralism, that conceive of the organisation mainly in terms of internal conflicts of interests, collective bargaining and union representation, are an equally unsuitable theoretical framework for understanding the employment relationship in this context. This is especially true where that relationship is largely defined and expressed in terms of conflict of cultures and values (Fox, 1974; Provis, 1996). We suggest that the 
employment problem in SSA expresses itself as a social and moral problem (notwithstanding underlying economic interests) and its analysis and resolution requires a theoretical framework that addresses the role of social institutions in 'normative regulation' (Ackers, 2002: 6). In that regard, we propose a modified version of Ackers' Neo-pluralist perspective as a more suitable theoretical framework for examining and explaining issues of work and employment management in SSA. Our argument is that although Neo-Pluralism is designed as a response to changes in the Western world of work, it is abstract enough to be adapted to the SSA context. In that respect, it can be the basis for an analysis that takes-in a wider-range of 'stakeholders' such as traditional family clans and religious brotherhoods, whose influences pervade SSA authority relations, and the emerging tensions, values, interests and expectations of the wider community. An analysis that is anchored in such a theoretical framework will facilitate a more holistic examination and explanation of the employment management problem and thus, the development of a more pragmatic model of HRM for SSA. Such a model will have structures for negotiations between formal organisations and Africa culture as the basis for institutionalising compatible elements of the 'African social-system' into formal policies and routines of organisations.

\section{Employment Management in SSA: A Historical Perspective}

Management theories and practices in SSA have been shaped and influenced by colonial ideology and capitalist modes of production. Of course, pre-colonial SSA had its own management systems that were typically small in size and homogenous in terms of their membership (Kiggundu, 1991) but, nevertheless, "had their own mode of selecting recruits, inducting them, maintaining discipline and rewarding employees' (Akinnusi, 1991: 161-2). However, in certain parts of SSA, these exclusive traditional

African management systems had ceased to exist even before the arrival of European colonialist. In most of the Sahel region of West Africa (see map below), for example, pre-colonial contacts between indigenous Africans and Arab traders had resulted in a significant Arab influence in the form of Islamic law and Muslim codes of conduct. Although this influence, like traditional African values and norms, has endured, the dominant management theories and practices in SSA evolved from colonial solutions to problems of capitalist production in Africa. Even so, analysing the employment problem solely in terms of the social reality of Africa's colonial past and ignoring or dismissing the relevance of the social realities that represent its precolonial experiences, could adversely affect our understanding of that problem. 


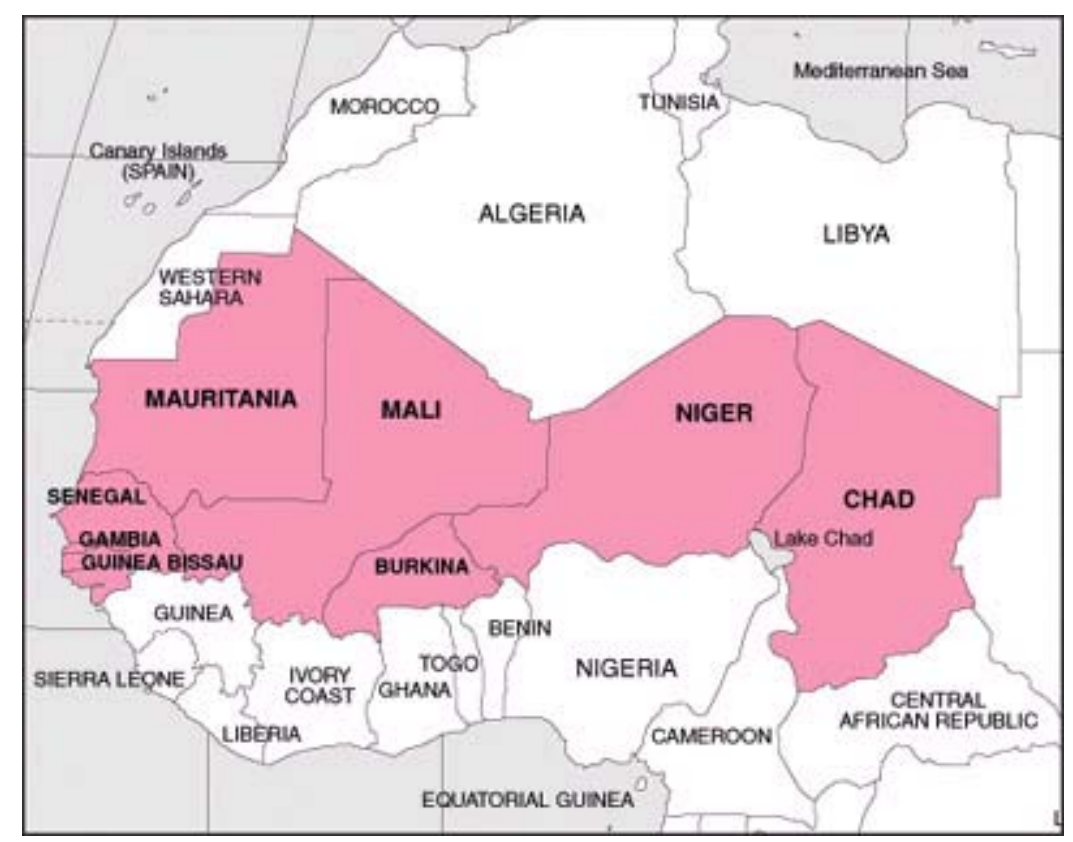

In reality, the SSA context is a contradiction that is manifested in the predominance of Western organisational forms, and the continuing manifestation of social values and behaviour that question the suitability of the values and objectives those organisations represent and promote. Consequently, what pertain are formal institutional and organisational forms that reflect the success of the colonial agenda, and individual attitudinal and behavioural patterns that represent the social resistance to that agenda. Although individuals are keen to enter into waged employment and adapt to the formal regulations and values of modern organisations, they do not consider these formal obligations to have precedence over the obligations and commitments they have as a result of their membership of the surrounding African community. As a result, the context under which management paradigms and practices operate, must take into account the value orientations and norms of precolonial institutions that still have more enduring influences on individual attitudes and behaviours. In the Sahel, the institutions and social structures that represent those values and norms include extended family clans and religious brotherhoods, which contested with colonialism for social hegemony over the inhabitants of this region in middle and late $19^{\text {th }}$ century.

However, the relevant management theories and practices that concern this paper are those that evolved first from the colonial solution and most recently from SAP. It is the suitability of these theories and practices for SSA that is in question here. 
Despite the differences in ideology and perceptions of empire, before World War II, all the colonial powers depended on forced labour supplied by traditional rulers for the development, expansion and maintenance of empire (Bourrett, 1963; Kimble, 1965; Cooper, 1983; Akinnusi, 1991; \& Kamoche, 2000). As a result, Bourrett (1963) and Kimble (1965) noted that the 'HR function' received prominence early in the colonial period. Akinnusi (1991) and Kamoche (2000) attribute the early indigenisation of the 'HR function' in Africa to sheer expedience. Traditional rulers were depended upon as suppliers of labour, and subsequently, as 'pacifiers of the same in the face of vociferous demands and complaints' (Kamoche, 2000:40).

At the end of the War, as Africa's potential as a source for capitalist development dawned on the colonial powers, the labour question assumed a new dimension. By then both Britain and France saw Africa as the source of new economic initiatives for the recovery of their empires from the destruction and indebtedness of war. These new initiatives however, were to follow the European model whereby the expansion of the imperial economy and the development of colonised peoples are seen as mutually consistent objectives that are better pursued through the employment of private capital and initiatives (Cooper, 1990). The fundamental problem for this European-model, however, was the apparent disjunction between capitalist conceptions of work and economic reality and the African's lack of economic urge to work in the manner consistent with the capitalist ideal (Cooper, 1987). In the colonialists' view:

'To a greater degree, ... the African is independent of paid work for his subsistence, ... and the idea of continuous employment as his main support is entirely strange, and in fact repellent, to his mentality' (Orde Brown, 1946 quoted in Cooper, 1987: 126).

The idea of continuous employment may not be as repellent to the African as these lines suggest. However, the observation represents the significant issues of the labour problem at the time. On the one hand, it reflects capital's difficulty in obtaining steady and reliable work from workers who retain their traditional access to land and their connection with the pre-colonial economic system (Cooper, 1983 \& 1987). On the other hand, it reflects the African worker's concerns regarding the implications of capitalist work time and space discipline for her/his alternative obligations and relationships that are the sources of the social bonds that have held his/her society together for centuries. The history of employment management in SSA, therefore, is 
not simply the history of the economic relationship between capital and labour. It is also the history of the socio-cultural conflict between Western capitalism and African society. In that respect, the employment problem is a social problem that requires sociological analysis and understanding, which in turn, demands we look 'beyond the workplace to the wider questions about African society and its place in the modern world' (Cooper, 1987: 4).

For colonial capital, the labour and employment problem in the immediate post war period was to get 'Africans to produce what colonial states wanted in acceptable quantities in the context of Africa's own societies and of a colonial state with limited resources' (Cooper 1981: 1). The colonial solution was to create a separate body of African workers who would 'cease to be African' (Cooper, 1987: 9). This strategy was based on an indictment of the African worker and African society that required the creation of a separated group of African workers, who needed to be protected from the primitive and brute ways of tribal society (Cooper, 1983 \& 1987). In East Africa, for example, a Royal Commission set up to study the labour situation following labour unrest in Kenya in the 1930s, suggested the replacement of the:

'Static security' of "African tribal society," that puts all members down to a low common denominator with a more dynamic system of property relations that would allow efficient producers to accumulate land and constitute themselves into a solid, progressive farming class, just as those detached from the soil would be made into a responsible working class' (Cooper, 1987: 129).

The British objective therefore, was to create an African working class that is cut-off from the commitments and social relationships of African society, but unequal with the colonial expatriate worker. The French on their part, were concerned with nurturing a class of African 'evolue' who in the grand design of French colonial ideology, would represent the empire's African elite that would be the object of 'assimilation'. There was concern, however, that such ambivalent attitudes to African culture could be 'disruptive of those intimate personal bonds, which are the ultimate source of moral restraint' and social security and control in traditional African society (Lord Hailey, 1945: 604 cited in Cooper, 1987). These concerns, along with fears of unpredictable patterns of industrial conflict in the aftermath of the industrial unrest in East Africa, led to the consideration of alternative forms of social security and social control (Cooper, 1987). In this regard, state-organised trade unionism was considered to be a potentially viable structural replacement to 'traditional African 
system of family or tribal mutual aid' (Luyt, 1949: 36 cited in Cooper, 1987). The ideas, solutions and practices that are outlined in the preceding paragraphs are quite consistent with the main thrust of Western thinking regarding employment management. As Cooper (1987), observed:

'The quest for a stable, disciplined, properly socialized work force. ... The stress on the role of the state in planning the needs of workers over the course of their life-cycle, the emphasis on managerial control in the workplace, the belief that industrial relations could be rationalized if the proper institutions were created, and the notion that all these dimensions of planning and control could be analyzed in terms of the technical demands of modern production and objectively determined human needs had been part of European and American thinking about industry and the welfare state for much of the twentieth century' (p. 135).

This thinking and the policies and practices that emanate from it are the employment management legacy of colonialism in Africa.

In the absence of alternative know-how or perhaps, for purposes of political and economic expedience, post independence governments simply perpetuated these colonial management systems (Jackson, 2002). The unfortunate consequence in terms of analysis and solutions is that the employment management problem in SSA is still not conceived of as a largely social and moral problem that requires sociological analysis. Whether contemporary HRM, in its various conceptions will fare any better remains to be seen. It is the view of this paper that it simply represents yet another unsuitable 'classical' economic solution to the sociological problem of the SSA employment relationship.

\section{Economic Reforms and the Emergence of HRM}

Personnel Management remained the basic administrative title until the early 1980s, when with the introduction of Economic recovery and Structural adjustment programmes (ERP/SAP), the rhetoric of Human resource management (HRM) emerged on the SSA scene. ERP/SAP introduced new and unfamiliar challenges that brought into sharper focus, and in a different political context, the sociological nature of the employment management problem in SSA. This paper is not about the broad policy stances and objectives of these interrelated programmes. However, because it 
is important to identify the broader theoretical framework on which HRM is based, we discuss, briefly, the main employment management objectives of these programmes and the political and economic context for the introduction of HRM in SSA. This discussion and a review of the 'explicative forms of HRM' (Keenoy 1999), question the suitability of HRM for a context where, alternative commitments and social organisation are not hangovers from the past, "but concrete realities, strongly rooted in their urban neighborhoods and rural villages' (Cooper (1983: 10).

As a construct, distinct from traditional Personnel Management, HRM emerged from the United States in the 1980s (Guest, 1987) as corporate America's reaction to "the Japanese 'Janus' and model of excellence" (Legge, 1995: 79). Coincidentally, it was during this period that SSA was in the throes of a serious economic crisis and in urgent need of foreign capital to avert total collapse. Foreign capital however, was available mainly through capitalist financial institutions that were largely under American control and access was therefore, contingent on the adoption and implementation of economic reform programmes that were consistent with the neoliberal economic principles that were in vogue in Washington and London at the time. It is reasonable to assume that when initiatives are intended (as was the case with SAP) to create a competitive market environment and induce efficiency and economy in management of organisations (Davis, 1991; \& Debrah, 2001), practices that are perceived to be antithetical to those objectives must be targeted. Employment practices in SSA have been variously described as sources of corruption (Berge, 1981), paternalistic (Dia, 1993; \& Pinto \& Morpe, 1994), and supportive of an 'external role-set' rather than the objectives and goals of the organisation (Kiggundu, 1989; \& Blunt \& Jones, 1992). For these reasons, issues of employment management were central to the structural adjustment agenda. In that respect, ERP/SAP focused on workforce restructuring through redundancies and mass retrenchment, and the liquidation or commercialisation public sector enterprises. These activities, directly and/or indirectly, involved issues of employment management.

In The Gambia ${ }^{1}$, for example, where the ERP/SAP were introduced in June 1985 , there was a two-prong approach respectively targeting central government and public enterprise workforces. The employment problem, as defined by the World Bank and IMF was mainly about the size of the public sector workforce and whether public

\footnotetext{
${ }^{1}$ This paper is based on the $\mathrm{PhD}$ work of Alhajie and his experience working in The Gambia
} 
resources could continue to sustain the size and rate of employment. In particular, the public enterprise workforce was considered to be a significant contributor to the poor performance of parastals, because it was deemed to be economically large and characterised by inappropriate skill mixes and staffing ratios (GG, 1985; \& McPherson, 1995). The net results of reform policies in terms of the employment management, was the retrenchment of about a third of the public sector workforce (Nti, 1989; \& McPherson, 1995), and the introduction of lucrative incentive packages for managers of public enterprises and senior government officials. In terms of the future management of labour, there were obvious indications that HRM was the approach of choice. Personnel departments in both private and public sector organisations were renamed as HR departments headed by HR directors and the new language of HRM was evident. ERP/SAP therefore, constituted the broad economic policy framework used to introduce the rhetoric (if not the practice) of HRM to the SSA context.

However, these purely economic solutions, like the ones before them, had to contend with the traditional relationship structures and influences that were said to have undermined Western solutions to the employment problem. The World Bank, for example, observed that despite mass retrenchment exercises, employment costs in most SSA countries had increased and suggested that a number of retrenched workers were finding their way back into public sector employment (WB, 1991). These observations suggest, yet again, that purely economic and rationally determined solutions will face challenges from an 'African social-system' that supports alternative relationship structures and social organisations.

\section{'The List': Workforce Restructuring in The Gambia Ports Authority}

An instance (one we are familiar with) when the influences of traditional relationships structures and institutions were brought to bear was in the case of The Gambia ports Authority (GPA) in the late 1980s. As part of the public enterprise reform agenda, the Authority entered into a 'performance contract' with the government of the Gambia (the sole owners) in June 1987. Under the terms of the contract, the GPA was required to carryout extensive labour audits in order to determine its staffing requirements to meet the targets that were set out in the contract. Following the audit exercise, a 'labour reserve pool', comprising of about 285 employees (about a third of its workforce) who were, at the time, considered to be surplus to requirements, was created. These employees were to remain on the pay roll until the end of the financial 
year by which time their redundancy would have been established, and they would be retrenched. However, during that period the Authority could redeploy individuals from the 'list' as and when required. By the end of the year, however, over half of the original 'list' had been redeployed. This, despite the fact that there were no changes to the performance contract in terms of targets and the Authority did not engage in any undertakings that were not envisaged when the list was drawn.

To the unfamiliar observer, corruption and political pressure may suffice as an explanation. However, significantly, the external pressures that were brought to bear on senior managers of the Authority came from sources other than the formal political patronage that is often referred to in the literature. Instead, employees who were targeted for retrenchment simply reverted to traditional and religious relationship structures to secure their jobs. In that regard, the 'matriarchs' and 'patriarchs' of the extended family clans and the 'Saints' who preside over the religious brotherhoods and maintain their influence through perceived mystical powers were the greatest sources of pressure. As a result, most of the decisions relating to these redeployments were taken in the informal environment of the home rather than the formal work environment. In most instances, the process leading to the decision will involve the particular worker or elders from her/his extended family buying 'cola-nuts' and making approaches to senior managers either directly or through the elders of the relevant manager's family clan. Alternatively, they may approach a religious leader who they believe has some influence over the manager or other important member(s) of her/his extended family. The manager would then be summoned by elders of his own family or by the religious leader and the case of the particular employee would be put to her/him. The decision to deploy is made there and then and the HR department simply receives instructions to implement. The point of this story is that although business organisations are urged to ignore these external influences, those who are actually involved with managing people find it very difficult or even impossible to heed such advice.

\section{HRM and the Sub-Saharan Context}

The belief that this new approach is suitable for the SSA context is based on the analyses of the employment management problem in largely rational economic terms. In that respect, the employment problem is seen simply as an economic problem that required economic solutions. Workforces need to be reduced and the demand for formal sector employment needed to be suppressed. According to Storey 
(1989) most formulations show HRM as having 'soft' and 'hard' versions. In the context of ERPISAP then, mass redundancies and retrenchments are consistent with 'the quantitative, calculative and business-strategic aspects of managing the head count resource' like any other economic factor - 'hard version' HRM (Storey, p. 8). On the other hand, the 'utilitarian instrumentalist' orientation and 'developmental humanism' disposition, as Legge (1995) noted, suggests two different but 'not necessarily incompatible emphases' (p. 66). Ultimately, however, the goal of 'soft' HRM is to motivate employees to commit to the cause of the organisation over and beyond all other causes. In that regard, the objective of HRM strategies and practices is to inspire employees 'to go beyond mere compliance to management by internalising the goals of the organisation and behaving accordingly' (Redman and Wilkinson, 2001: 8). Management, for its part, is required to create strong organisational cultures with 'more or less homogenous value systems' (Tayeb, 1996: $189)$ and clear goals and objectives and encourage all employees to identify with it (Hofstede, 1980; Schein, 1992; Storey, 1995; \& Tayeb, 1996).

However, even after the introduction of practices that are consistent with the main conceptions of HRM, the literature on employment management in SSA resonates with colonial concerns regarding the negative implications of the traditional social system for good management practices (Kiggundu, 1989; Blunt \& Jones, 1992; WB, 1989 \& 1990; \& Dia, 1996). In their 'models of organisational culture', Blunt and Jones (1992) categorised organisational cultures in SSA as 'Fragmented (Negative) Cultures' that are characterised by 'isolated pockets of positive values and belief' that do not constitute part of any rational organisational value system (p. 196). This is attributed to the 'existence of social systems,' that 'constitute a fertile wider social environment for the emergence of fragmented cultures of this type' (P. 196). In terms of individual attitudes and behaviour, work is simply 'an instrumental activity; that is tolerated in order to obtain money'. As a result, involvement is 'calculative ... and work neither constitutes a central life interest nor a source of psychologically significant experiences in terms of self-actualisation' (Blunt \& Jones, 1992: 205).

Kiggundu, (1989) presented a similar conclusion. Referring to Leonard's (1986) suggestion that, in terms of strategic management, 'the largest part of a leader's efforts are probably directed at factors external to his or her organization...' (p. 58), he warned that: 
'A distinction must be made between organization-environment and extraorganizational tasks. The former are strategic management tasks designed to benefit the organisation as a whole, while the latter seek to satisfy individual or collective interests outside the organization' (Kiggundu, 1989: 57).

Like Blunt and Jones, Kiggundu attributes SSA's management problems to the social environment that gives 'preference' to '... cultural and religious values and practices that emphasize the influence of the past on the present rather than the independent planning of the future' (Kiggundu, 1989: 63). The problem with this conclusion is that it echoes colonial diagnoses and revives the solution of creating an African workforce, in Africa, that is completely detached from African society.

These views and conclusions reflect the increasing interest in organisational analysis in SSA in the aftermath of the economic crisis and the introduction of SAP. However, they also reflect a persistent misconception of the employment management problem in SSA. Most of what is described in the literature as African management systems and managerial attitudes are not African per se (Jackson 2002). According to Jackson, the 'centralised', 'dictatorial' and 'bureaucratic' management styles that are associated with Africa 'are mostly representative of a post-colonial heritage, reflecting a theory X style' which allows little worker initiative and rewards a narrow set of skills simply by financial means' (Jackson, 2002: 1002). Their continuing existence could be attributed to the staying power of the employment management legacy of colonialism and/or the extent to which that legacy has been perpetuated by postindependence governments to protect vested political and economic interests. It may also be that this is the only way post-independence managers knew how to manage (Jackson, 2002). The significant point, however, is that the employment management problem, which continues to be predominantly analysed in terms of the economic demands and rationally determined needs of global capitalism (Cooper, 1987), remains a sociological problem of norms, values and interests. 'Culture can offer only a partial explanation of why people think and behave as they do...' and 'no worthwhile theory of change can exclude objective economic interests and material forces' (Kuper, 1999: xi \& 199). We are not suggesting that Africans are totally nonmaterialistic and that economic factors have no bearing on their attitudes and behaviours. For this reason, we use the phrase 'African social-system' rather than the customary 'African thought-system'. However, we would argue that a 'scientific, economic reductionist' analysis of exchange relationships in African society (Marie, 
2000), suggests a very superficial understanding of the cultures and values that underpin those relationships. While there is reason to believe, that especially in urban Africa, economic factors have become relatively more significant in the exchange equation, even in the urban context, objects and actions of relative economic insignificance dominate the exchange relationship. In the Sahelian region, for example, the sharing of Cola nuts (an object of little economic significance) represents the consummation of most social occasions and events including marriages, naming ceremonies, the announce of the arrival of a guest, and funerals.

The relative success of colonial solutions to African economic management problems had more to do with the ability of empire to impose its vision of time, space and authority on the African worker than to the ingenuity of those solutions themselves. Even in the present context of the global economic system, capitalism has largely failed to have the kind of impact on the relationship between capital and labour in Africa that it had during the Western industrial revolution. In SSA capitalist development continues to 'articulate with precapitalist modes of production, sapping their autonomy without changing their internal logic, and draining adult male labor into wage employment without taking over the burdens of supporting women, children, and nonworking men' (Cooper, 1983: 16). It is in this broader social and moral context, rather than the economic and 'rational' concerns of business organisations, that the employment management problem in SSA must be analysed, understood and resolved. Since the introduction of SAP, there has been an emerging stream of analysis that utilises cultural and social factors as a key to understanding and explaining HRM in SSA. This stream of research has conceptualised the problem in terms of the contrast between African culture, values and social organisation, and Western perception of organisation (Nzelibe, 1986; Dia, 1991 \& 1996; Blunt \& Jones, 1992; Mbigi, 1997; Kamoche, 1997 \& 2000; Jackson, 1999 \& 2002; \& Beugre \& Offidile, 2002). The emerging argument is that the African worker is also burdened with obligations and commitments that are imposed by the social organisations and institutions that influence and regulate normative conceptions and behaviour within the wider African community. The worker's concern for these obligations and relationships has always mediated her/his attitude and behaviours towards the 'rational' objectives and policies of formal organisations. Consequently, organisational analysis and management in the SSA context must fashion ways to understand the social organisations and relational structures of the wider African community in order to address the key issues in the employment relationship more effectively. 
Conceptions based on cultural comparisons at the 'inter-continental' level (Jackson 2002) have suggested various diagnoses and solutions for the employment management problem in SSA. Dia (1996), for example, identified a 'disconnect' between traditional African values and transplanted organisational forms and management approaches. He proposed, therefore, a paradigm that seeks to reconcile the two. Others have used Hofstede's (1980) cultural dimensions to explain the problems of organisational management in SSA (Blunt and Jones, 1992; Dia, 1996; and Thomas and Bennendix, 2000). Within the framework of comparative cultural analysis, there are calls for management models for SSA to incorporate elements of the 'African thought-system' into formal organisational policies and routines (Kamoche, 1997 \& 2000; and Beugre and Offidile, 2002). Jackson (1999 \& 2002) suggested an analytical approach based on the different cultural perceptions of the value of human beings, as the foundation for a renaissance of African managerial systems. In this theoretical paper, we propose the employment of a more grounded theoretical framework of organisational reality as the fundamental basis for examining, understanding and resolving the employment management problem in SSA. We argue that only on the basis of such an analysis, can we understand the expectations of the wider African community and its enduring social influences on individuals and, as a result, evolve contextually suitable HRM models. Such models will enhance the capacity of organisations to go beyond crude absorption of elements of the 'African thought-system' and instead, institutionalise the more compatible elements of the 'African social-system' into formal policies and routines.

\section{Frames of Reference and the SSA context}

Employment relations 'frames of reference' are important because they 'determine judgement, which in turn determines subsequent behaviour' (Fox, 1966: 390). In terms of HRM, they constitute the 'main selective influences' (Newcomb, 1950, in Fox 1966: 390) on managerial attitudes and behaviour in terms of policies and their execution, as well as employees' attitudes and behaviours towards those policies and practices. Traditionally, there are two employment relations 'frames of reference' regarding organisational reality - Unitarism and Pluralism (see Ackers and Wilkinson, 2003). Although Unitarism appears to have made a grand comeback in the form HRM, the Unitarist theory of the organisation is still widely regarded as an implausible conception of organisational reality (Coopey \& Hartely, 1991; Provis, 1996; \& Kamoche, 2000). This is even more true of the SSA context, where there are 
alternative values, norms and forms of social organisation external to the organisation that are more representative of every day reality.

Since the introduction of capitalist modes of production and Western organisational forms, the key issue of the employment management problem has been the 'undesirable' influence of African cultures, values and norms on the African's concept of work and her/his attitude towards waged employment (Cooper, 1983 \& 1987). Despite the apparent cultural heterogeneity within SSA, as the literature indicates, the expression of the employment management problem in social terms is not only enduring but also rather pervasive. More recently, in the Southern African context, the literature has focused on the issue of the influence of traditional African values and norms in organisational analysis (Mbigi and Maree, 1995; Mbigi, 1997; Horwitz et al, 2002; and Jackson, 2002). The call for an 'African Renaissance' (Makgoba, 1999; and Jackson, 2002;) is largely a post-apartheid South Africa phenomenon. However, the expression of this phenomenon in terms of 'Ubantu' - 'humanist', 'communal' 'stakeholder' orientation to HRM (Mbigi and Maree, 1995; Mbigi, 1997; \& Jackson, 2002) suggests a specific African management philosophy based on some specific ethnic South African cultural values and norms.

Cultural diversity suggests that in other parts of Africa, a managerial renaissance may require a more complex mix of values and norms. For example, in the Sahelian countries (see map on page 4), individual attitudes and behaviours are influenced by both traditional ethnic (tribal) cultures, social organisations and institutions, and Arabic culture and institutions in the form of Islam and Muslim brotherhoods. The extent and nature of pre-colonial contacts between Africans and Arab traders in this region have left an indelible and unique cultural mix whereby the dichotomy between traditional African and Arab values and practices is significantly blurred. Here, rules and codes of conducts that were formulated by Muslim clerics to govern every aspect of life in pre-colonial societies (Davidson, 1967) are still relevant in the formation and maintenance of individual and communal relationships. As a result, despite the length and intensity of Western contact through colonialism and the current global economic and political systems, the extended family clan and the Islamic brotherhoods continue to have enduring influences on individual perceptions and actions.

These normative influences and their implications for public administration in Senegal is the subject of Cruise O'Brien's (1975) Saints and Politicians: Essays in the organisation of a Senegambian Peasant Society. In this analysis of the relationship 
between national politicians, traditional chiefs and the 'saints' who preside over Senegal's major religious brotherhoods, O'Brien argued that in most post-colonial states in Africa, the boundaries of the state do not correspond with those of national identity. As a result, in order to comprehend the nature of the influences that effect individual as well as communal values and acts, several dimensions of society including the traditional family clan and religious brotherhoods - must be examined (O'Brien, 1975: 153). In this context, the nation state, through its institutions and legal frameworks, has a direct policy influence on formal organisational structures and strategies. However, the informal organisations that exist within the formal organisation represent the elaboration of the alternative values and social organisations of the extended family clans and religious brotherhoods. These dimensions alone cannot, however, account for the attitudes and behaviours of individuals. Economic factors such as labour markets and the social security that comes with waged employment are also important influences. The emerging consensus however, is that understanding the informal influences and their manifestation in the attitudes and behaviours of African workers, is the key to understanding the issues involved in HRM in SSA (Dia, 1991 \& 1996; Kamoche, 1997 \& 2000; Beugre \& Offidile, 2002; \& Jackson, 1999 \& 2002). Here, we argue that although understanding cultural differences and their implication for differences in perceptions is useful, the search for theories that connect cultural values to HRM policies and practices (Cray and Mallory, 1998) in Africa, requires a more fundamental rethink of notions of organisational reality in that context.

\section{External influences on Individual attitudes \& Behaviours in Formal organisations}

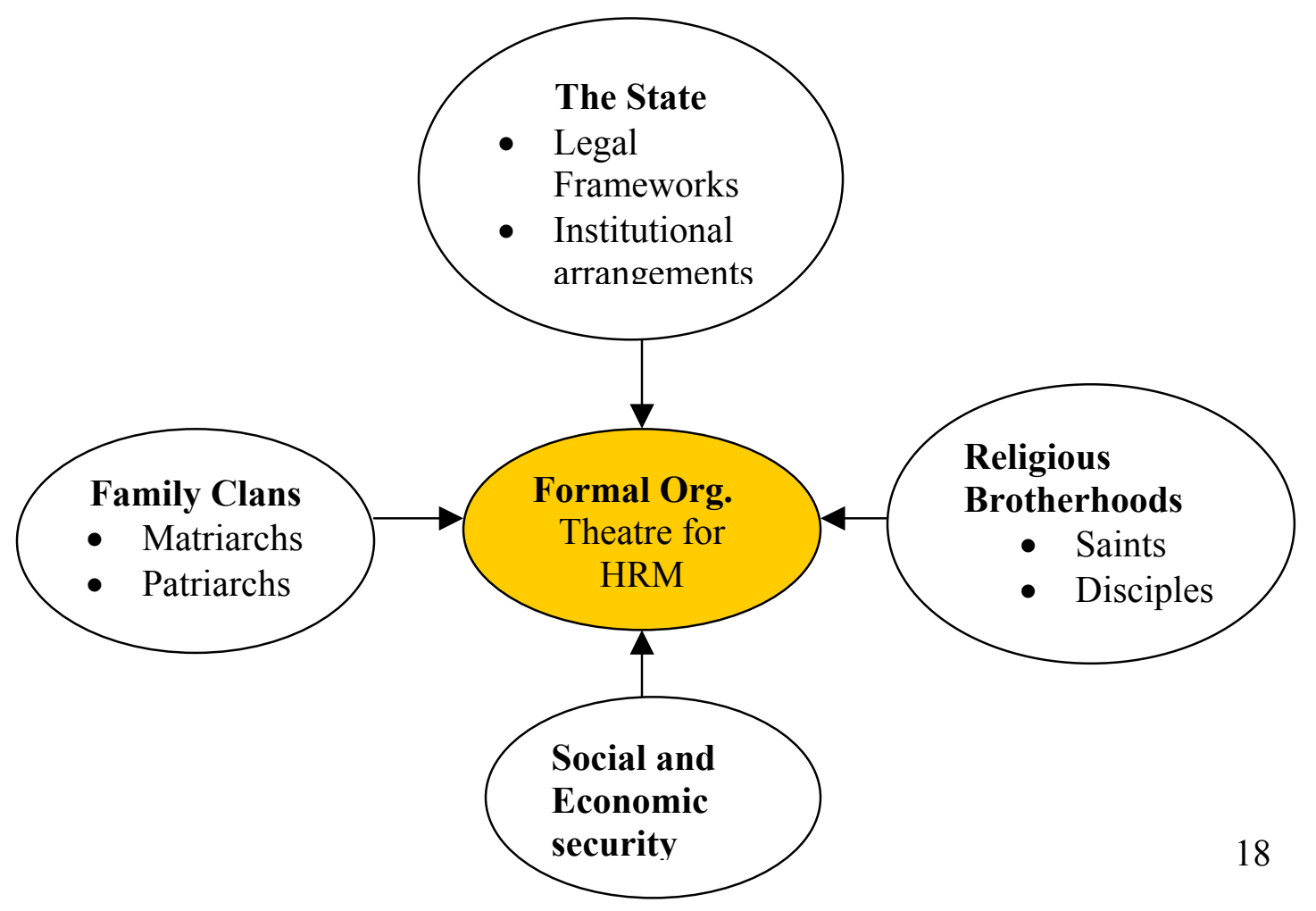


The main alternative to the Unitarism is the Pluralist theory of organisational reality. This 'frame of reference' is seen as a more plausible conception of organisational reality because it rejects the notion of the organisation as a team with unified interests and objectives. Instead, it emphasises the reality and/or potential for the existence of many and divergent interests, and 'rival sources of leadership and attachment' (Fox, 1966: 393; see also, Coopey \& Harteley, 1991; Kamoche, 2000; Ackers, 2001). However, when the employment relationship is discussed in terms of divergence in cultures and values as well as interests, traditional formulations of 'pluralism' become problematic (Provis, 1996; and Ackers, 2002). The 'new orientation' (Provis, 1996) whereby issues in the employment relationship are discussed as much in terms of conflicts of values as interests, suggests, a 'shift in the problem of order' (Ackers, 2002: 3) in the employment relationship. As a result, both Provis and Ackers have argued for a rethink of the conceptions of the processes and structures 'by which differences' in the employment relationship 'are reconciled' (Provis, 1996: 473). Ackers (2002) suggests a 'Neo-pluralist' framework that will enable organisational analysis to go beyond the workplace to take-in a wider range of stakeholders and tensions over values as well as interests.

Comparison of Pluralism and Neo-pluralism (Source: Ackers, 2002)

1970s Pluralism

Interests

Work place conflict and economic order

Trade unions and collective bargaining

The forward march of labour

The frontier of control

Joint regulation

\section{Neo-pluralism}

Interests and values

Social exclusion and social cohesion

Social institutions and social commitments

Civil society and communal rights

Stakeholding and social expectations

Ethical employment regulation

\section{The New Orientation and Pluralism}

'All told, traditional formulations' of pluralism 'have tended to emphasize interests and to obscure the difference between pluralism of interests and pluralism of values' (Provis, 1996: 477). However, some early formulations did in fact, emphasise values 
and attempted to draw distinctions between interests and values. Flanders (1968), for example, observed 'industrial conflicts may be rooted in a clash of values as well as conflict of interests' (p. 16). In Beyond Contract, Fox (1974) argued that the 'search for social justice also requires a considerable degree of 'shift in values, institutions and social philosophy' (p. 359) and in Man Mismanagement (1985), he stressed the importance of 'values' to comprehending individual behaviour in the work place. The performance of the organisation he said 'depends in the last resort upon conceptions in the minds of the men and women they recruit for these purposes' (p. 1). Although Fox was writing in terms of individuals' 'conceptions of how they ought, or would be best advised in their own interests' ( $p .1$ ), he also noted that some of these conceptions may be the products of influences and loyalties that are outside the organisation. As a result, he warned that focusing attention 'on the organisation alone, to the exclusion of the wider society in which it is embedded ... is fatal for a full understanding of the issues involved' (p. 4) in the employment relationship. In this regard, he wrote: 'pluralist perspectives on society and the enterprise must be seen not as socially neutral but as having great ideological significance' (Fox, 1985: 25).

When defined in terms of 'values' instead of just 'interests', pluralism invokes a 'genuine motivational force' (Provis, 1996: 474) strong enough to engender moral instead of calculative involvement (Rokeach, 1979; \& Fox, 1985). Pluralism so conceptualised, recognises that in addition to common managerial and employees interests, there is also 'plurality of groups whose association arises from a common culture or identity' (Philips, 1993: 151). Collective and social identity are part of the 'new conceptual repertoire' indicating that even in Western societies, 'the problem order which has been located traditionally by Industrial Relations (IR) in the work place, has shifted to the relationship between work and society' (Ackers, 2002:3). Although this reorientation of emphasis is noted in the IR literature, its implications for IR theory seem to go amiss. As a result for example, even in the West, there is still paucity of research on the relationship between work and family.

Even in the Western world of work, to quote Provis (1996: 487): 'so far as industrial relations processes are concerned, it is a particular difficulty for value pluralists to say what parties ought to be recognized and encouraged in the process'. We wish to emphasise that wage disputes, work organisation and similar issues that are often the subject of collective bargaining remain relevant in the SSA context and unions do exist and articulate these issues. However, formal policies for dealing with workplace conflicts of cultures and values are conspicuously absent. For example, in our 
experience, organisations do not have formal policies for regulating employees' attendance of 'funerals' and other traditional social events that are often described as causes for absenteeism and inefficiency. The resolution of these social issues, that tend to dominate the employment relationship, are largely left to the discretion of individual managers, and quite often, their decisions depend on how much informal external influence individual workers can bring to bear. Here unions, are not the main representative channels for dealing with some of the more significant issues in the employment relationship. To fully understand these issues and fashion contextually suitable ways to resolve them, requires, in the first instance, an analytical framework capable of taking-in the wide-range of stakeholders whose influences impact on the relationship between labour and management. This would conceive of the employment problem not simply in terms of the internal organisational conflicts between management and workers, but also, in terms of the normative traditional relationship structures that influence workers' perception of the employment relationship. In that regard, both Unitarism and traditional formulations of Pluralism (Fox, 1966; \& Clegg, 1979) need revisiting.

\section{A values and Interests Institutionalisation model of HRM for SSA}

It would be misnomer to describe the emphasis on culture and values in employment relationship in SSA as 'a new orientation'. Although the dominant approaches to organisational analysis tends to dismiss traditional African cultures and values as archaic sources of corruption and inefficiency, the literature continues to attribute employment management problem in SSA to traditional relationship structures and values (e.g. Blunt \& Jones, 1992; \& Kiggundu, 1989). It should therefore, be quite obvious, that by analysing SSA's employment management problem in terms of the economic expectations of corporate America and rationally determined management objectives, the socio-cultural issues that are at the heart of the problem are being misconceptualised and as a result, misunderstood. When the employment relationship is discussed in terms of culture and values, what is required is the sociological analysis of workplace relationships (Watson, 1995) involving the critical analysis of workers' behaviour and attitudes, and more importantly, the influences and values that are the antecedents for those attitudes and behaviour. That way, to paraphrase Fox (1985: 5), we can examine and understand employment management in the context of the wider social setting within which this mutual relationship is conducted, rather than merely focusing on 'the institutional relationship between employers and trade unions' (Ackers, 2002: 5). The focus moves to the 
cultural values and social organisations of the wider community and how they influence and shape individual perceptions and behaviour towards formal organisational objectives, policies and practices. These concerns assume added urgency and relevance in the SSA context.

A key argument is that an assessment of the appropriateness of managerial theories and practices must, of necessity, consider the cultural and social considerations that question the assumed universal applicability of existing theories and practices. The issue of 'suitability' (or should that be unsuitability) is a recurring theme in the literature on organisational management in SSA (Abudu, 1986; Nzelibe, 1986; Leonard, 1987; Ahiauzu, 1986; Kanungo, 1990; Kamoche, 1993 \& 2000; \& Thairu, 1999). According to Nzelibe (1986), 'whereas Western management thought advocates Eurocentrcism, individualism, and modernity, African management thought emphasizes ethnocentricism, traditionalism, communalism, and cooperative team work' (p. 11). Although the structures and processes of formal organisations in SSA are based on Western models and value systems, Africans who work in them bring to the workplace attitudes and behaviour that are largely shaped by the 'African social-system'. These values underpin the attitudes and behaviour that individual workers elaborate as they attempt to interpret, construct, and give 'meanings to things, structures, and processes at the industrial work place' (Ahiauzu, 1986: 47). Consequently, the debate about organisational management in SSA must also be a debate about the compatibility of elements of the indigenous 'African social-system' with the transplanted management paradigms used to manage African workers.

What is suggested here is neither an unthinking adoption of Western theoretical concepts, nor the view that SSA is a homogeneous society with a uniform culture and social and value systems. Indeed, it is important to realise, that 'in spite of the relative uniformity in the essence of the "African thought-system" African culture is in reality a melange of ... "sub-cultures"/linguistic groups' (Kamoche, 2000: 55). There is hardly a SSA country with a homogenous population. In addition to the diversity within countries, there is also significant cultural diversity between countries. As a result, there are differences in educational systems, social stratification, and legal and institutional arrangements between countries (Tayeb, 1995). Quite often, what are described as 'national cultures' are in fact neither indigenous nor foreign (Ankomah, 1985; \& Abudu, 986) but 'hybrid monstrosities' that are the consequent of colonialism and an ill-considered post-independent strategies (Abudu 1986: 18). This cultural diversity suggests that conceptualising a specific African culture, values and contexts 
requires a degree of vigilance posing practical and theoretical difficulties for the adaptation of foreign models to the SSA context (Kamoche, 2000). It would, however, be absurd to suggest an outright rejection of foreign theoretical conceptions and managerial practices. Western concepts can be potentially useful for our understanding of organisational and managerial phenomena if they are abstract enough to 'offer insights about the range of options available for crafting organizations and enhancing their effectiveness' (Kamoche, 2000: 56).

Neo-pluralism can be a useful framework for three reasons. Firstly, the suggestion of the involvement of a wide-range of 'stakeholders', values and interests in the employment relationship, resonates with our argument for organisational analysis in SSA to shift from exclusive organisational and managerial concerns and take on the other broad social dimension of the wider society. Secondly, by bringing 'the concept of civil society' into the employment relationship debate (Ackers, 2002: 10), it represents a framework for formal organisations to tap into sources of 'communal energy' in the form of traditional Clan networks and Religious brotherhoods. In that respect, African paradigms regarding motivation, work organisation, dispute resolution and public relations could be useful. Finally, the notion that 'long-term trust relationships in both economic and social spheres depend on strong normative institutions' (Ackers, 2002: 17), suggests a framework that could bring into the analysis, the external cultural and social variables that also help to shape the employment relationship. This is particularly relevant in a context where the key issues in the relationship are socio-culturally expressed. In these regard, it could be adapted into a values and interests-institutionalisation model of employment management for SSA. This paradigm is not dismissive of all aspects of mainstream HRM. It suggests, however, that viable HRM models for SSA must go beyond the crude consideration and incorporation of elements of the 'African thought-system'. Instead, it proposes negotiation between formal organisations and Africa culture as the basis for institutionalising the more compatible elements of the 'African socialsystem' into formal HRM policies, strategies and routines.

This model rejects the notion that significant changes in individual attitudes and behaviours can be brought about by managerial strategies based exclusively on the 'integration of positivist, scientific, and objective ways of regarding human interrelations instead of passive acceptance of the values and institutional arrangements of society' (Nzelibe, 1986: 9). In the absence of a clear distinction between specific values of traditional 'normative' institutions and the common values 
that emanate from a common association in a nation state, policies and strategies are adopted on the basis of 'national cultural' considerations. Quite often, such policies bring into sharper focus, the incompatibility of imported and indigenous cultures and values. The re-emergence of unitarism, in the guise of HRM and in the context of a neo-liberal agenda merely reflects the extent of 'cognitive dissonance' between traditional SSA values and the economic objectives of global capitalism. In this context, the rationally determined needs of the nation-state are confused with the specific socio-cultural concerns of African society. As a result, policies that simultaneous deny many their sources of livelihood, while giving the few contextually unethical incentives, are considered viable in societies where the egalitarian distribution of the outcomes of collective economic endeavour is valued.

Although the Values and interests-institutionalisation model is not based on 'traditional' perspective of organisational reality, it resonates with the central ideas of some of the management paradigms that have recently been suggested for SSA.

\section{Neo-Pluralism: A Values and Interests Institutionalisation Model of HRM \\ External context $\longrightarrow$ Organisational context \\ (Philosophy \& strategy) \\ HRM Policies \\ \& Practices}

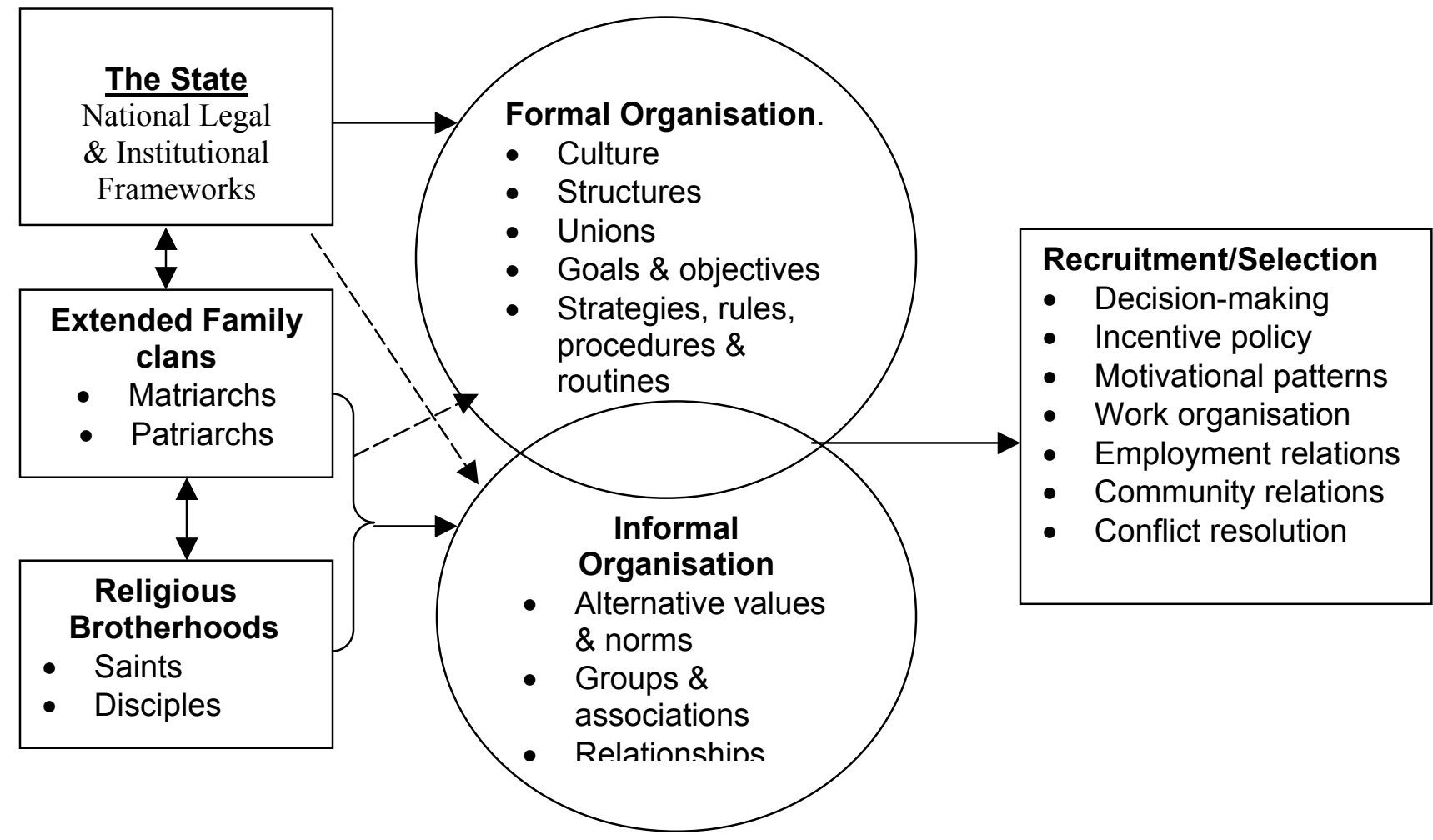

The view that some elements of the 'African thought-system' should be considered for inclusion into formal organisational policies and practices is the key argument of 
the Reconciliation paradigm (Dia, 1996), the Processual, strategic model (Kamoche 2000), and the Culture-fit model (Beugre \& Offodile's 2001). However, conceptualisations and solutions are theoretically suspect and have little practical value if they do not evolve from a holistic and realistic analysis of the problems they are intended to redress. The Reconciliation paradigm was the outcome of a World Bank sponsored study and conceived of in the context of the institutional arrangements for national reform policy delivery. Data was collected mainly through 'institutional environment assessment exercises' involving senior government official engaged in the implementation of public policy reforms and development administration. Even in the context of policy delivery, the assumption that the reconciliation of cultures and values can be based on the exclusive imagination of senior government bureaucrats who run policy delivery institutions is, to say the least, rather absurd and self-defeating.

Beugre \& Offodile's (2001) Culture-fit model emerged from a comprehensive review of the literature on cultural patterns and management practices in SSA. Therefore, they highlighted the African propensity for autocratic styles of leadership (Kiggundu, 1988; Jones et al 1996; \& Blunt \& Jones, 1997), large 'power distance' and collectivism (Hofstede, 1980) and ascribed great importance to social relationships (Takyi-Asiedu, 1993). They argued for the integration of 'modern management techniques into African systems of management' and the eradication of aspects of African culture that are not 'conducive to better management practices' (Beugre \& Offodile, 2001: 543). The problems, however, are that the 'autocratic' style of leadership they associate with Africa has little to do with 'African culture' while the 'Organisational change-oriented attitudes' strategy they proposed reflected a unitarist managerialism. The suggestion of a 'transformational' style of leadership, as the basis for changing attitudes - lacked any empirical evidence that this style of leadership was more effective (Hendry \& Pettigrew 1992: 155). It reflected, instead, an appreciation for 'the aspect of the American Dream that highlights the value of strong leadership, backed-up by a strong organisational culture, both reflecting the spirit of 'rugged, entrepreneurial individualism' (Leege 1995: 87). In terms of the practical managerial techniques that African managers are urged to adopt, the Culture-fit model argues for neo-liberal unitarist managerial practices without giving much thought to the infrastructural and social contingencies that are essential for the successful adoption of those practices. 'Business process re-engineering', 'just-intime (JIT)', 'total quality management (TQM)' and collaborative forms of management (Beugre \& Offodile, 2001:545-547) all represent practical techniques directed 
exclusively at managerial concerns and the rational economic objectives of business. JIT is a strategy for 'securing time economies in the circuit of capital' and eliminating 'any non-value adding operation from the' production 'process' (Legge, 1995: 221). 'Business process re-engineering' on the other hand, is simply a more fashionable term for what Legge (1995: 139) calls 'various forms of relational contracting'. In terms of contingencies, the success of these techniques depends to a great extend on a certain level of customer sophistication and communication infrastructure, both of which are lacking in the SSA context.

Kamoche's (2000) processual, strategic model of HRM for Africa is an 'internal resource' perspective of HRM based on Penrose's argument 'that the uniqueness of firms arises from the heterogeneity available or potentially available from their internally held resources' (Kamoche, 2000: 57). Although it questions the propriety of conceptualising organisational commitment from a unitarist perspective, it discusses the firm's internal resources in terms of the 'behavioural capabilities' available to management and discusses 'the worker's frame of reference' in terms of its utility to the organisation. 'The interface between strategic management and HRM' according to Kamoche, 'should ... be understood in terms of what the firm can do with the skills, abilities and talents (resources) of its employees' (p.57). Therefore, he argues for organisational analysis to shift 'away from the dominant external environment paradigm, to the level of the firm (p. 57).

This suggests some major differences between Kamoche's model and the one proposed by this paper. In terms of level of analysis, the call for analysis to focus on the organisational level suggests that it is possible to fully comprehend the traditional African values that underpin individual attitudes and behaviours by simply observing actions that represent the elaboration of those values within the organisation. In that regard, elements of the 'African thought-system', as they are played out in organisational relationships, should be understood on management's terms and utilised for managerial purposes. The Values and Interests Institutionalisation model on the other hand, advocates negotiations between the formal organisation and African culture. In that case, the evaluative criteria for understanding 'workers' frame of reference' and their utility to the organisation are not the exclusive discretion of management. The issue then, is not just about the utility of elements of the 'African thought-system' to rationally determined organisational objectives and goals. It is also about the organisation recognising the significance that employees attach to those elements in terms of the values and paradigms of an alternative 'social-system' 
they represent, and that workers' individual and collective obligations as defined by the alternative social system.

It is our contention, that in terms of both analytical approaches and prescriptions, the three HRM models discussed above project unitarist views of organisational reality in SSA. Their underlying perception of organisational reality is a fundamental difference they have with the value and Interests-institutionalisation model. We suggest, that one cannot, with any reasonable degree of success, determine the compatibility of elements of traditional African cultures with foreign managerial theories and practices solely on the basis of managerial imagination and the evaluative criteria of formal organisations. Similarly, in the SSA context, the employment relationship cannot be conceived of simply in terms of the internal conflicts of (economic) interests between management and labour unions. Although the value and Interests-institutionalisation is also about the role of African cultural values in the management of people in organisations in Africa, it expresses these values in terms of the 'African socialsystem' rather than the 'African thought-system'. The latter connotes that elements of 'African culture' can be simply eradicated through indoctrination and management training. In these terms, the 'African social-system' is more representative of the values, norms and social organisation that are at the centre of the HRM problem in SSA.

More importantly, however, the model proposed in this paper, is about the terms and conditions on which elements of the 'African social-system' are defined and evaluated for inclusion into formal organisational policies and practices. In that respect, workers' values and interests and the informal attitudes and behaviours they manifest in the formal working environment that represent them, should not be taken for granted. The manner in which these 'informal' values and norms are considered for inclusion into formal organisational policies and routines should, to some extent, reflect evaluative criteria that is consistent with the 'African social-system'. A clear distinction must be made between the cultural values of the wider SSA society, and cultural behaviour that is often referred to in terms of systemic corruption, alienation, inefficiency and bad practice. These negative attributions do not constitute traditional African values. Instead, they are behaviours that are the consequence of the 'circumstance' and 'contingencies' (Abudu, 1986; \& Henderson, 1993) relating to post-colonial patterns of public and corporate governance. The absence of the kind of social safety-nets that exist in Western countries and the prevalence of 'pitifully low wages' have engendered 'systematic corruption' on the part of those who are left to 
look after an extended family of unemployed and sometimes infirm relatives (Henderson, 1993). The object here is not to justify corruption and inefficiency, but rather, to emphasise the point, that the corruption and inefficiency that is associated with public and corporate governance in SSA should not be attributed to the culture and social values of traditional SSA society because in those societies themselves, 'no one thinks it' [corruption] 'is morally right' (Henderson 1993: 81).

We are mindful of the multiplicity and diversity of SSA cultural characteristics. Nevertheless, there are salient cultural patterns and values that are common enough to allow for cautious generalisation of an 'African social-system'. In terms of work organisation, motivation, conflict resolution, decision-making and employment relations, knowledge of the paradigms of the extended family clans and religious brotherhoods could be very useful to business organisations. In terms of employment relations and public relations, for example, in addition to trade unions, formal organisations can harness the potential of informal group leaders whose leadership may be solely based on their empathy with the values and norms of these external normative institutions and 'stakeholders'. Bearing in mind that we are discussing a social context that is largely 'pre-contractual', in the sense that contracts are largely unwritten and obligations are mainly enforced through complex webs of social relationships and routines, it is important that motivational patterns include elements that will enable individuals to 'safeguard' their 'social assets' (Fox, 1974: 158). Therefore, there must be a balance in the underlying assumptions for patterns of motivation so that organisational policies regarding motivation can also include elements that are socially gratifying. In that regard events such as 'the village funeral' should not be seen in terms of wastefulness and absenteeism (Hansen, 2002), but rather, as an event that helps to reinforce the social bonds which are the foundation of society and as having benefits that are more social than economic (Dia 1991: 12).

African culture is by nature collectivist (Hofstede, 1980; \& Dia, 1991) not in terms of the simple aggregation of people but in terms of 'communalism' and 'kinship' (O'Brien, 1975). As a result, the average African values and tends to be more comfortable as part of a group (Beugre \& Offidile, 2002). This communal orientation is potentially useful for work organisation and decision-making. Although African political leaders and managers are described as generally autocratic (Kiggundu, 1989; \& Blunt \& Jones, 1992), 'the pre-eminence of the group', requires that decision-making in traditional Africa society is often based on consensus (Beugre \& Offodile, 2001: 538; Weil, 1971; \& Dia, 1991). In terms of work organisation, there is 
potential for team building and teamwork as long as these work designs are consistent with the values of "groupism, familysm and communalism" (Kamoche, 200: 60).

\section{Conclusion}

This paper argues the case for reframing organisational reality in SSA and developing more suitable employment management paradigms for that context. We have reviewed the literature on organisational analysis and HRM in SSA and argued that most of the conclusions regarding employment management in general and employee attitudes and behaviours are based on unsuitable conceptions of organisational reality. The negative attributions that are often associated with the African worker are based on analyses of the employment problem in terms of the technical demands of modern production and rationally determined management objectives (Cooper, 1987). We have argued that unless the employment problem is conceived of in social terms and subjected to more holistic sociological analysis, it will remain intractable and unresolved.

The introduction of HRM in the context of the neo-liberal revival of the 1980s represents yet another attempt to revisit the problem. This latest attempt as the literature indicates, has met with dismal failure. The literature that has emerged since the introduction of economic recovery and SAP, suggest that the problem has still not been wholly understood (Nzelibe, 1986; Kiggundu, 1989; Blunt \& Jones, 1992; Dia, 1996; \& Beugre \& Offidile, 2002; Jackson, 2002) and for that matter, the remedies have been misconceived and practically ineffective. This is largely due to the fact that organisational analyses in SSA have tended to focus on internal organisational phenomena and, with the exception of the state, significant external social dimensions have been ignored or dismissed as irrelevant. There are two reasons for this. First, the fact that organisational and management research in, and about SSA, is largely dominated by the American approach to organisational analysis. This means that the State is considered in very minimal terms and traditional 'normative' institutions and social relationships are dismissed as archaic sources of inefficiency and bad practice. Secondly, and this is the important theoretical argument, we suggested that there is a lack of a suitable conceptual framework for a more holistic analysis of the employment management problem in SSA. We have argued that when the major issues in the employment relationship are expressed as conflicts of 
cultures and values, Western conceptions of organisational theory are inadequate as frameworks for analysis.

In that regard, we have proposed the Neo-pluralist framework (Ackers, 2002) as a more useful approach for explaining and understanding employment management in SSA and developing a contextually suitable HRM model. Even though Neo-pluralism redefines the pluralist perspective in the wake of new orientations in employment relations in Western society, it is abstract enough to be adapted to the SSA context. In that respect, it has "a functionalist emphasis on institutions...and is based on a more expansive and flexible sociology of normative regulation" (Ackers, 2002: 6). In the SSA context, where the influences of traditional normative institutions and organisations pervade authority relations within formal organisations, the neopluralist framework can be adapted for a more holistic examination and comprehension of the employment relationship.

The values and Interests-institutionalisation model of HRM we have proposed is a sociological development from a neo-pluralist perspective of organisational reality based on the traditional and communal etos of the 'African social-system'. This will facilitate the institutionalisation of the values and interests of the wider African community into formal HRM policies and practices. Although this model does not assume the existence of homogenous African cultural characteristics, it conceptualises an 'African social-system' based on salient cultural characteristic that are common to most SSA societies. It argues that in terms of generating 'high trustrelations' (Fox, 1974), the content and conduct of the employment relationship in SSA will have greater impact if they include elements of that 'system'. It proposes the creation of structures that will serve as linkages between organisations and the wider community and seeks a voice for a wider-range of stakeholder. Here, voice is not just in terms of Tyler's (1994) value-expressive model of justice, which argues for the opportunity to speak as a value in itself. Rather, what is envisaged is voice in terms of determining evaluative criteria for what counts as proper or improper conduct (see Marchington et al, 2001). In that regard, the model advocates negotiation and cooperation between formal organisations and African culture. By co-operation, we do not mean the superficial and duplicitous faking of co-operation and pretence of the existence of shared interests (Ackers, 2002: 8), but one that values group solidarity and real social bonds that are corner stones of communal existence. 


\section{Reference}

Abdu, F. (1986) 'Work Attitudes of African, With Special Reference to Nigeria', International Studies of Management and Organisation, Vol. 16 (pp. 17-36)

Ackers, P. (2001), 'Pluralism'; 'Unitarism' in T. Redman \& A. Wilkinson (Eds.) The Informed Student Guide to Human Resource Management, London: Thomson Learning, (pp. 194-195 \& 263-264).

Ackers, P. (2002), 'Reframing employment relations: the case for neo-pluralism'. Industrial Relations Journal, Vol. 33:1 (pp. 2-19).

Ackers, P. and Wilkinson, A. (2003) Understanding Work and Employment: Industrial Relations in Transition. Oxford: Oxford University Press.

Ahiauzu, I.A (1986) 'The African Thought-system and work behavior of the African Industrial man'. International Studies of Management and Organization, vol.26 (pp. 37-58).

Akinnusi, D. (1991), 'Personnel management in Africa: A Comparative analysis of Ghana, Kenya and Nigeria', in C. Brewster and S. Tyson (Eds.) International Comparisons in Human Resource Management, London: Pitman.

Ankomah, K. (1985) 'African Culture and Social Structure and Effective Public Administration and Management Systems in Africa', Indian Journal for Public Administration, April/June (pp. 394-412).

Beer, M., Spector, B., Lawrence, P., Quinn Mills, D. and Walton, R. (1985) Human Resource Management: A General Manager's Perspective, Glencoe, ILL: Free Press.

Berg, R.J. (1981) Accelerated Development in Sub-Saharan Africa: An Agenda for Action, Washington, DC: World Bank.

Beugre, C.D. and Offodile, O.F. (2001) 'Managing for organizational effectiveness in sub-Saharan Africa: a culture-fit mode', International Journal of Human Resource Management, Vol. 12:4, June (pp. 535-550).

Blunt, P. (1990) 'Recent Developments in Human Resource Management: The good, the bad, and the ugly', International Journal of Human Resource Management, Vol. 1:1 (pp. 45-59).

Blunt, P. and Jones, M.L. (1992) managing organisations in Africa, Berlin: de Cruyter.

Brown, L.D. \& Brown, J.C. (1983) 'Organizational microcosms and ideological negotiation'. In M.H. Bazerman \& R.J. Lewicki (eds.), Negotiating in organization. Beverly Hills: Sage (pp. 227-248).

Clegg, H.A. (1979) The Changing System of Industrial Relations in Great Britain. Oxford: Blackwell. 
Cooper, F. (1983) 'Urban Space, Industrial Time, and Wage Labour in Africa' in F. Cooper (Ed.) Struggle for the City: Migrant Labour, Capital, and The State in Urban Africa. Beverly Hills \& London: Sage.

Coopers, F. (1987) On the African Waterfront: Urban Disorder and the Transformation of Work in Colonial Mombasa. New Haven \& London: Yale University Press.

Cooper, F. (1990) 'The Senegalese General Strike of 1946 and The Labour Question in Post-War French Africa', Canadian Journal of African Studies, Vol. 24:2.

Coopey, J. and Hartley, J (1991) 'Reconsidering the Case for Organisational Commitment, Human Resource Management Journal Vol. 1 (pp. 18-32).

Cray, D. \& Mallory, G.R (1998) Making Sense of Managing Cultures. London: Thomson.

Cruise O'Brien, D.B. (1975) Saints \& Politicians: Essays in the Organisation of Senegalese Peasant Society. London: Cambridge University Press.

Davidson, B. (1967), A History of West Africa 1000-1800. London: Longmans.

Davies, R.J. \& Weiner, N. (1985) 'A cultural perspective on the study of industrial relations'. In P.J. Frost, L.F. Moore, M.R. Louis, C.C. Lundberg \& J. Martin (eds.), Organizational Culture. Newbury Park, Cal.: Sage.

Davis, J. T. (1991) 'Institutional Impediments to Workforce Retrenchment and Restructuring in Ghana's State Enterprises', World Development, 19:8 (pp. 9871005).

Debra, Y. A. (2001), 'Human resource management in Ghana' in P. Budhwar \& Y. A. Debra (Eds.) Human resource management in Developing Countries, London: Routledge (pp. 190-208).

Dia, M. (1993) A Governance Approach to Civil Service Reforms in Sub-Saharan Africa, Washington D.C: World Bank.

Dia, M. (1991) 'Development and Cultural Values in Sub-Saharan Africa: It is time we understand the psychology of economic decision making in Africa. One view of the issue'. Finance and Development, December (pp. 10-13).

Dia, M. (1996) Africa's management in the 1990s and beyond: Reconciling Indigenous and Transplanted Institutions, Washington D.C: World Bank.

Flanders, A. (1968) experiments in Industrial Democracy: a study of the John Lewis partnership. London: Faber.

Fox, A (1966) 'Managerial Ideology and Labour Relations', British Journal of Industrial Relations, Vol. IV (PP. 366-378). 
Fox, A. (1974) Beyond Contract: Work, Power and Trust Relations, London: Faber \& Faber.

Fox, A. (1985) Man Mismanagement, London: Hurchinson.

Guest, D (1987), 'Human Resource Management and Industrial Relations'. Journal of Management Studies, Vol. 24:5, September, (pp. 503-521).

Henderson, E.V. (1993) 'The Ethical side of Enterprise'. In G.D. Chryssides and J.H Kaler (eds.), An Introduction to Business Ethics. London: Chapman and Hall (pp. 50-82).

Hendry C. \& Pettigrew, A. (1990) 'Human resource management: an agenda for the 1990s', International Journal of Human Resource Management, vol. 1:1 (pp. 17-44).

Hendry, C. and Pettigrew, A (1992) 'patterns of Strategic Change in the Development of Human Resource Management'. British Journal of Management, Vol. 3:3 (pp. 137-156).

Government of The Gambia (1985) Economic Recovery Programme (ERP), Banjul, The Gambia: Government Printer.

Government of The Gambia (1987) Administrative Reform Programme (ARP), Banjul, The Gambia: Government Printer.

Government of The Gambia (1987) Management Performance Contract between the Government of The Gambia and The Gambia Ports Authority, Banjul, The Gambia: National Investment Board.

Government of The Gambia (1994) Economic Management Sector Adjustment Loan (SEGAL), Banjul, The Gambia: Government Printer.

Hansen, C.D. (2002) 'Organizational Change and the Village Funeral in Cote 'Ivoire', Conference Paper, Budapest, Hungary.

Hofstede, G. (1980) Culture's Consequences: International Differences in Work Related Values, Beverly Hills: Sage.

Jackson, T. (1999) "Managing Change In South Africa: Developing People and Organisations", International Journal of Human Resource Management, 10:2 (pp. 306-326).

Jackson, T (2002) "Reframing human resource management in Africa: a crosscultural perspective", International Journal of Human Resource Management, 13:7 (pp. 998-1018)

Kamoche, K. (1993) 'Toward a Model of HRM in Africa', in J. B. Shaw, P.S. Kirkbride, K.M. Rowland and G.R. Ferris (Eds.) Research in Personnel and Human Resource Management, Greenwich, CT: JAI Press (pp. 259-278). 
Kamoche, K. (1997), 'Managing Human Resources in Africa: Strategic, Organizational and Epistemological Issues', International Business Review, Vol.6, (pp. 537-558).

Kamoche, K. (2000) Sociological Paradigms and Human Resources: An African context, Aldershot: Ashgate.

Kamoche, K. (2001) 'Human resource management in Kenya' in P. S. Budhwar and Y. A. Debrah (Eds.) Human Resource Management in Developing Countries, London: Routledge (pp. 209-221).

Keenoy, T. (1991) 'The roots of metaphor in the old and the new industrial relations'. British Journal of Industrial Relations, 29:2 (pp. 313328).

Keenoy, T (1999) 'HRM as a Hologram: A Polemic' Journal of Management Studies, 36:11-23).

Kiggundu, M.N. (1989) managing Organizations in Developing Countries: An Operational and Strategic Approach, Hartford, CT.: Kumarian Press.

Kiggundu, M.N (1991) 'The Challenges of Management Development in SubSaharan Africa', Journal of Management Development, 10:6 (pp. 32-47).

Kimble, D. (1965) A Political History of Ghana, Oxford: Clarendon.

Kuper, A. (1999) Culture: The Anthropologists' Account. Cambridge, Mass: Harvard University Press.

Legge, K. (1995) Human Resource Management: Rhetorics and Realities, Basingstoke: Macmillan.

Leonard, D.K. (1987) 'The Political Realities of African Management', Report of Workshop on the Management of Agricultural Projects in Africa, Washington DC: USAID.

Lubeck, P.M. (1987) The African Bourgeoisie: Capitalist Development in Nigeria, Kenya and the Ivory Coast, Boulder, CO: Lynne Reiner.

Makgoba, M.W (1999) African Renaissance. Cape Town: Tafelberg.

Marchington, M., Wilkinson, A., Ackers, P. And Dunden, T. (2001) Mangement Choice and Employee Voice. London: CIPD.

Marie, A. (2000) "Household Strategies for Survival 1600-2000: Fission, Faction and Cooperation". In L. Fontaine \& J. Schlumbohm (eds.), International review of social history, supplement 8. Cambridge: Press Syndicate.

Mbigi, L. 7 Maree, J. (1995) Ubuntu: The Spirit of African Transformational Management. Randburg, S. Africa: Knowledge Resources.

Mbigi, L. (1997) Ubuntu: The African Dream in Management. Randburg, S. Africa: Knowledge Resources. 
McPherson, M.F. and Radelet, S.C. (Eds.) (1995) Economic Recovery in The Gambia: Insights for Adjustment in SSA, Cambridge, MASS: Harvard University Press.

Nti, J. (1989) 'The impact of Structural Adjustment on the Effectiveness of Public Service Personnel' in M.J. Balogun and O. Matahaba (Eds.) Managing Economic Reforms, Hartford, CONN: Kumarian Press.

Nzelibe, C.O. (1986) "The Evolution of African Management Thought", International Studies of Management and Organization, vol.26 (pp. 6-16).

Pinto, R.F. and Morpe, A.J (1994) Projectizing the Governance Approach to Civil Service Reforms: An Institutional Environment Assessment for Preparing a Sector Adjustment Loan in The Gambia, Washington, D.C: World Bank.

Provis, C. (1996) 'Unitarism, Pluralism, Interests and Values', British Journal of Industrial Relations, 34:4 (pp. 473-495).

Redman, T. and Wilkinson, A. (2001) Contemporary Human Resource Management: Text and Cases, London: Prentice Hall.

Rokeach, M. (1979) "From Individual to Institutional Values: with special reference to the value of science". In M. Rokeach (ed.), Understanding Human Values. NY: Free Press (pp. 47-70).

Schein, E.H. (1992) 'coming to a new awareness of organizational culture'. In G. Salaman, S. Cameron, H. Hamblin, P. Iles, C. Mabey and K. Thompson (eds.), Human Resource Strategies. London: Sage (pp. 237-253).

Storey, J. (Ed.) (1989) New Perspectives in Human Resource Management, London: Routledge.

Storey, J. (1992) Developments in the Management of Human Resources, Oxford: Blackwell.

Storey, J. (1995) 'Human resource management: still marching on, or marching out?' in J. Storey (Ed.) Human resource management: A Critical Text, London: Routledge.

Storey, J. (Ed.) (2001) Human Resource Management: A Critical Text, London: Thomson Learning, $2^{\text {nd }}$ Edition.

Takyi-Asiedu, S. (1993) "Some Socio-cultural Factors Retarding Entrepreneurial Activities in Sub-Saharan Africa", Journal of Business Venturing, vol. 8(pp. 9198).

Tayeb, M.H (1996) The Management of a Multicultural Workforce, New York etc: Wiley \& Sons.

Watson, T. (1995) Sociology, Work and Industry. London: Routledge ( ${ }^{\text {rd }}$ Edition). 
Weil, P.M. (1971) 'Political Structure and Process among the Mandinka: The Village Parapolitical System' in C.T Hodge (ed.) Stories of the Manding, Bloomington, IND: Indiana University Press.

Whipp, R. (1991) 'Human Resource Management, Strategic Change and Competition: The Role of Learning', International Journal of Human Resource Management, 2:2 (pp. 165-192).

World Bank (1986) World Development Report, Washington, DC: World Bank.

World Bank (1989) Sub-Saharan Africa: From Crisis to Sustainable Growth, Washington, DC: World Bank.

World Bank (1992) Governance and Development, Washington, DC: World Bank. 